\title{
NEW INVESTMENT PROJECTS IN THE ROAD CORRIDORS AND THE IMPROVEMENT OF THE POTENTIAL ACCESSIBILITY IN POLAND
}

\author{
Tomasz Komornicki, Marcin Stępniak \\ Institute of Geography and Spatial Organization \\ Polish Academy of Sciences \\ Twarda St. 51/55, 00-818 Warsaw, Poland \\ t.komorn@twarda.pan.pl,stepniak@twarda.pan.pl
}

\begin{abstract}
The purpose of the study, whose results are reported in the present paper, was to assess the changes in the spatial accessibility, resulting from the realisation of large road investment projects in Poland in the period 2004-2013. Attention was primarily focused on changes in overall accessibility and on investment projects, constituting three chosen case studies. The method, selected for the measurement of the level of spatial accessibility and of its changes, was based on the indicator of potential accessibility. Each analysis was carried out in parallel in three dimensions: European, national, and regional. It was stated that the improvement in the international and national accessibility, which took place in Poland due to the road projects, was highly uneven in space. It was determined by the location of the routes constructed and the distribution of the demographic potential in space. The resulting distribution of accessibility became more polarised, this being inevitable in the situation of undertaking numerous projects within a short time. The projects realised served more the international and inter-metropolitan connections, while their influence on the improvement of the situation within the provinces was smaller. The study confirmed the earlier apprehensions that the motorways might produce the "tunnel effect" (understood as limitation of the service to uniquely the long-distance connections). This sort of threat is decidedly smaller in the case of the expressways. It was also demonstrated that the correct location of the nodes might have a perceptible impact on the spatial reach of the positive effects from the projects.
\end{abstract}

Keywords: potential accessibility, Poland, road projects.

\section{Introduction}

The purpose of the study, whose results are reported in the present article, was to assess the changes in the spatial accessibility, being the effect of the realisation of large road projects in Poland in the years 2004-2013. The study was performed in the framework of the research project Multicriteria assessment of the influence of selected road corridors on the natural environment and on the socioeconomic development of the adjacent areas (no. N N306 564940) financed with the resources from the National Science Center. Attention was mainly concentrated on the changes in accessibility in general terms and on the investment projects, constituting three selected case studies: 
- construction of the motorway A1 over the segment Pruszcz Gdański-Grudziądz;

- construction of the motorway A4 over the segment Wrocław-Opole;

- upgrading of the national road no. 8 over the segment Radzymin-Wyszków to attain the parameters of the expressway, together with construction of the ring road of Wyszków.

In terms of the background for these analyses the current (as of the end of 2013) differentiation of the accessibility levels in Poland was presented, along with the scale and spatial structure of improvement of accessibility, resulting from the realisation of the road investment projects in the years 2004-2013. Based on the assumptions adopted the reference model of spatial accessibility was elaborated for the year 2013, and four models of changes in the levels of accessibility: one for the entire period considered, 2004-2013, and three models of change for the particular case studies.

The chosen method of measuring the level of spatial accessibility and its changes was the indicator of potential accessibility. Each of the analyses was carried out in parallel in three dimensions: European, national, and regional, assuming, at the same time, two different travel durations: short travels (with the median travel time of 30 minutes) and long travels (with the median amounting to 90 minutes).

\section{Potential accessibility - methodological prerequisites}

Spatial accessibility is a multidimensional phenomenon, this fact finding its reflection in the complexity of methods and techniques of investigations. Accessibility can be measured with the infrastructural equipment, distance, as well as with the cumulative, personified, or potential indicators (Geurs \& Ritsema van Eck 2001; Geurs \& van Wee 2004; Komornicki et al. 2010; Rosik 2012). In the analyses performed the last of the indicators mentioned was applied, based on the connections between all the origin-destination pairs of nodes, and admitting the assumption of the higher significance of more important (more attractive) travel destinations, and of the negative correlation between distance and the strength of the link between the origin and the destination. It was assumed that the attractiveness of the destination, called also "mass", is represented by the population numbers, inhabiting the particular administrative units in 2012 (according to the data from the Central Statistical Office), while distance between the centres was measured with time. The "classical" potential model was used in the study, according to which the value of the accessibility indicator at unit $i$ is calculated from the formula:

$$
A_{i}=\sum_{j} g\left(M_{j}\right) f\left(t_{i j}\right)
$$

where $g\left(M_{j}\right)$ is the function of attractiveness of the destination $j$, measured with the population number, while $f\left(t_{i j}\right)$ is the function of spatial resistance or decay, that is - of the decrease in attractiveness of the travel destination (Hansen 1959; Harris 1954). All of the analyses were performed on the basis of the administrative breakdown of the country at the level of municipalities.

The indicator of the potential spatial accessibility is composed of several elements. The first of those is the so-called own potential, that is - the level of accessibility of the unit, resulting from its own mass, decreased according to the assumed mean duration of an average travel inside the given unit. This component is calculated for the $i$ th unit from the formula: 


$$
A_{i \text { Self }}=M_{i} \exp \left(-\beta t_{i i}\right)
$$

where $M_{i}$ denotes the own mass of the unit (i.e., the population number), while $t_{i i}$ denotes the average duration of an internal travel in unit $i$. This duration was calculated for each of the municipalities conform to the formula, proposed by D. C. Rich (1978), who assumed that an average internal travel corresponds to the half of the radius of the given unit:

$$
t_{i i}=\frac{0,5 \cdot \sqrt{\frac{\text { area }}{\tilde{O}}}}{\overline{v_{i i}}}
$$

while the average speed of internal travel in a unit was assumed to be equal $20 \mathrm{~km} / \mathrm{h}$. The so assumed speed is lower than that used in the studies for, e.g., Finland (Kotavaara et al. 2011), but it seems appropriate for Polish conditions, in view, in particular, of the quality of road surfaces, density of the road network, as well as an important share of the urbanised areas.

The second component of the potential accessibility indicator is the inner potential, resulting from the influence of the remaining masses (municipalities) $j$ in Poland. The third, last component, is the outer potential, defined by the influence of all the masses $k$, located outside of Poland. Consequently, the total value of the potential accessibility indicator $A_{i}$ for the municipality $i$ is equal

$$
A_{i}=M_{i} \exp \left(-\beta t_{i i}\right)+\Sigma_{j} M_{j} \exp \left(-\beta t_{i j}\right)+\Sigma_{k} M_{k} \exp \left(-\beta t_{i k}\right)
$$

One can encounter in the literature of the subject application of many different functions, used to represent the space resistance, such as, for instance, the logistic function (Geurs \& Ritsema van Eck 2001), the power function (Fotheringham \& O'Kelly 1989), or the exponential function (Spiekermann \& Schürmann 2007). In the studies concerning the changes in the level of accessibility, resulting from the realisation of definite projects, most often the latter function is used. This is true both for the assessment of changes, resulting from single transport-related projects (Gutiérrez et al. 2011; Stepniak \& Rosik 2013), and for the changes in accessibility, being the effects of realisation of the long-term programmes of extension of the transport networks (Holl 2007; Kotavaara et al. 2011; Spiekermann et al. 2013). For this reason, the decision was made to adopt the exponential function of coercion in space, that is, the following expression:

$$
f\left(t_{i j}\right)=\exp \left(-\beta t_{i j}\right)
$$

In the case of the function selected, the element, which allows for the modification of the shape of dependence, related to space resistance, is the parameter $\beta$, this parameter taking the values between zero and one. The higher the value of $\beta$, the faster is the drop of the significance of mass with distance. Estimation of the proper value of the parameter $\beta$ can be done in such a way that the drop of the importance of the destination mass correspond to the median of the travel time, linked with the given travel motivation (Spiekermann et al. 2013). In the investigations, carried out, two different values of the parameter $\beta$ were used, so as to diversify the changes in the level of accessibility, depending upon the nature of motivation and the length of travel. For the short trips (like commuting to work or school) it was assumed that the drop by half of the significance of interrelation between the two centres corresponds to travel time of 30 minutes (see, e.g., Warsaw Traffic Survey 2005), while for 
the longer travels this value was set at 90 minutes (see, e.g., KMR 2008). Consequently, the values of the parameter $\beta$ amounted to 0.023105 for the short trips, and 0.0075 for the long trips.

The second element, which influences the differentiation and the scale of the results obtained is the spatial reach (dimension) of the analysis conducted. Each of the segments of the road network fulfils a certain role, this role taking on a different character, depending upon whether we look at the given network from the international (European), national, or regional (e.g. province level) standpoint. Consequently, the actual change in the level of accessibility, resulting from the modernisation or construction of a given segment of the road network, may be different, depending upon the spatial dimension of the analysis that we adopt. That is why it was decided to perform all the analyses in three different spatial dimensions:

- the international one - accounting for the connections between all the municipalities in Poland, and the connections between these municipalities and the centres, situated outside of Poland;

- the national one - limited, in comparison with the preceding perspective, to the national connections, that is - assuming lack of influence on the level of accessibility from the centres, located outside of Poland, meaning that the value of the third (external) component is equal zero;

- the regional one - in which each of the provinces is analysed as a separate area, not connected with the remaining ones.

Ultimately, therefore, each of the analyses performed was carried out according to six various schemes, which are shown in Table 1 below.

Table 1. Variants of the analyses

\begin{tabular}{|c|c|c|c|}
\hline & & \multicolumn{2}{|c|}{ travel length } \\
\hline & & short $(\beta=0.023105)$ & long $(\beta=0.0075)$ \\
\hline \multirow{3}{*}{ 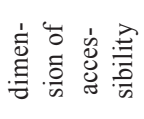 } & international & & \\
\hline & national & & \\
\hline & regional & & \\
\hline
\end{tabular}

Source: own elaboration.

The analyses made use of the spatial database on the road network, elaborated at the Institute of Geography and Spatial Organization, Polish Academy of Sciences, this database containing also the parameters of the elaborated model of traffic velocity (Rosik 2012). The road network used accounts for the jointly the following categories of segments of the road network: motorways, separate-traffic expressways, two-way traffic expressways, separate traffic national roads, two-way traffic national roads - classified into four sub-categories with respect to the width of the road (on the basis of data, acquired from the General Board of National Roads and Motorways), separate traffic provincial roads, two-way traffic provincial roads - classified into four sub-categories with respect to the width of the road (on the basis of data, acquired from the Regional Boards of National Roads and Motorways), as well as county and municipal roads (treated jointly as a single category). Each road segment was assigned a maximum admissible speed, resulting from the respective Road Code regulations, this maximum speed having been then decreased through consideration of: built-up areas, population density (as a reflection of the traffic intensity), and terrain relief (for the detailed description of the traffic speed model used, see Rosik et al. 2011). In the case of roads, situated outside of Poland, the average velocity of travel was assumed, resulting from the road code regulations for the individual countries (for the detailed description of the velocities assigned to roads outside of Poland, see Rosik 2012).

The analyses performed accounted for the state of the road network in the base variant, one reference variant (a historical one), and three variants for the individual case studies, prepared for 
the purpose of carrying out evaluation of changes in the level of accessibility ex post. The particular variants of the road network may, therefore, be characterised in the following manner:

- the base variant, corresponding to the state of the road network as of January 1st, 2013, with consideration of all the road projects underway;

- the "historical" reference variant, corresponding to the state of the road network as of January 1 st 2004 ;

- variant for the Al case study, corresponding to the base variant, with exclusion of the investment project, constituting the case study "A1 Pruszcz Gdański-Grudziądz";

- variant for the A4 case study, corresponding to the base variant, with exclusion of the investment project, constituting the case study "A4 Wrocław-Opole";

- variant for the $S 8$ case study, corresponding to the base variant with exclusion of the investment project, constituting the case study "S8 Radzymin-Wyszków"; in this case the segments of the road network, which were modernised owing to the realisation of the project in question, were assigned the parameters, corresponding to the situation from before the modernisation; the segments, built as new in the framework of the investment project in question, were treated as nonexistent.

In the further course of this paper, characterisation is provided of the differentiation in the levels of potential spatial accessibility in the base variant, for all the six variants of analysis (that is - for the short and long travels in the international, national, and regional dimensions). Attention was focused on spatial differentiation on the scale of individual municipalities and provinces. Side by side with the averages weighted by the population numbers of the values of spatial accessibility indicators in the municipalities of the particular provinces (with reference to the average weighted by the population for the entire country), the minimum and the maximum values are shown, observed in the provinces. The background for the detailed analyses of the selected case studies is complemented by the analysis of changes in the levels of spatial accessibility in all the six variants of analysis in the years 2004-2013.

\section{Poland in the European studies of spatial accessibility}

The changes in the positions of countries and centres within the transport system of Europe are well illustrated by the measure, constituted by the indicator of the potential accessibility, calculated for the entire continent, or for the so-called ESPON space. Studies of the thus conceived accessibility are being conducted for several years now mainly by the German teams (Spiekermann \& Schurmann 2007), and also for the needs of the ESPON projects (ESPON 1.2.1., 1.1.3, ESPON, SeGI, FOCCI). In the year 2001 almost entire Central-Eastern Europe was characterised by the relatively low values of the indicator. A jump-like change could be observed along some segments of the western boundaries of the area, which ought to be interpreted as the break in the faster chains of the infrastructural routes (this kind of situation was particularly well visible along the Polish-German and Hungarian-Austrian boundaries). Higher values (exceeding $120 \%$ of the average for the ESPON space) were observed mainly in some of the capital cities, owing to the airports, located there (Prague, Warsaw, Budapest), and in Bratislava (the neighbourhood of Vienna). Interestingly, the cartographic image has almost completely hid the infrastructural chains inside the countries of the region. Hence, the image is strongly influenced by the very geographic distance from the core area of the European Union (the so-called Pentagon). This was understandable in the situation, where the quality of the surface transport was uniformly low on the entire area in question - except for the fragments of the territories of Czechia and Hungary. In 2012 the spatial setting of the indicator values is already significantly different (Fig. 1), this being partly the consequence of the significant investments, 
made largely owing to the funds from the European Union. The ultimate image obtained indicates a distinctly higher polarisation regarding the potential accessibility. The boundaries between the new and the old member countries of the European Union are definitely less visible. In the cases of western Bohemia, western Slovakia, northern Hungary, and also of north-western Poland, connection took place with the zones of good accessibility in Germany and Austria. The spatial distributions of the values of the indicator considered for the remaining countries are still characterised by the existence of "islands" of better accessibility. This concerns, of course, first of all the new member states, but also, in some instances, the older members of the EU. Thus, in particular, the NUTS units, surrounding such cities as Wrocław and Gdańsk, distinguish themselves positively against the background of the neighbouring areas. Likewise, some of the transport corridors, into which significant European funds have been invested, are also clearly visible. This applies in a particular manner the two parallel corridors in Poland (Warsaw-Berlin and Dresden-Cracow-border with Ukraine, in both cases investments having been made into road and railway infrastructure). At the same time, though, more distinctly than at the beginning of the preceding decade, the least accessible zones can be seen, including, for instance, the north-eastern part of Poland, and that despite the investment projects undertaken.

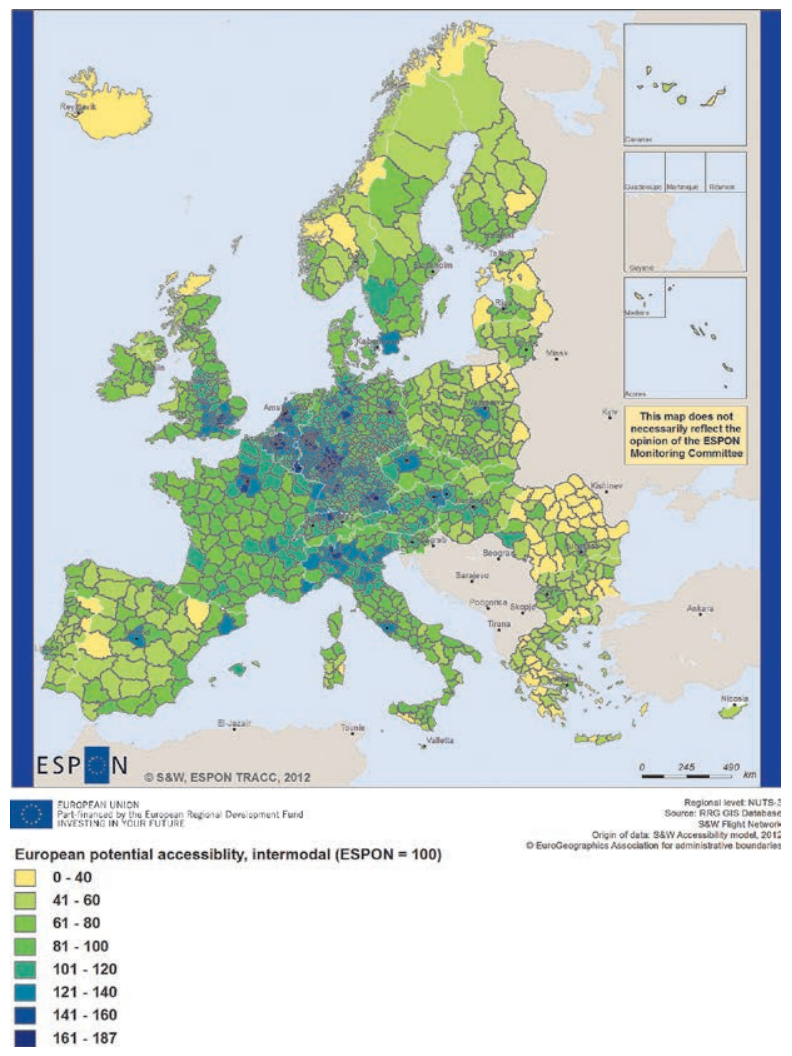

Figure 1. Multimodal potential accessibility in Europe (2012) Source: ESPON TRACC, Final Report, 2014, p. 96.

Summing up, it should be stated that Poland remains in Europe a peripheral country. This peripheral character is also reflected in the global relations (especially the Asian ones). The transport- 
related projects brought about an improvement in the situation, but this improvement was spatially selective and produced an increased transport-wise polarisation.

\section{Spatial accessibility of municipalities in 2013 and its changes in the years 2004-2013}

The distribution of the international accessibility, analysed in the framework of the present study (short travels), see Fig. 2, Table2, shows the generally best situation with this respect in the areas neighbouring upon the poles of Warsaw-Lodz, Upper Silesia-Cracow and Berlin (the German borderland). Besides, this accessibility is relatively better within the belt towards Gdańsk, associated with the course of A1 motorway. In the case of longer travels the image is less spatially differentiated. It shows a decrease of the value of the respective indicator from the German and Czech borders to wards the eastern and north-eastern directions. The decrease is slower along the directions of A2 and A4 motorways.

The level of national accessibility remains the highest in the area of Warsaw, and of Upper Silesia and Cracow. In addition, there are distinctly visible belts of better accessibility, related to the three main motorways. Hence, they encompass Wrocław, Poznań, and the Tri-City. The spatial distribution makes also other roads apparent. In southern Poland an area of a better accessibility borders upon the Czech Republic. Along the remaining borders more extensive zones of periphery can be seen. The area of better accessibility has increased in the recent years, and starts to more explicitly refer to the "hexagon", defined as the basic network of metropolises at the stage of elaboration of the new Concept for the Spatial Development of the Country 2030 (Korcelli et al. 2010). The areas, featuring the highest values of the indicator concentrate in the frameworks of the potential bi-polar settings of Cracow and Katowice, as well as Warsaw and Lodz. The image obtained confirms the proposition that the improvement of accessibility (also within the peripheries) is to the highest extent influenced by the transport projects situated centrally (in spatial terms) and those neighbouring upon the biggest demographic and economic potentials. As in the previous case, the image for the longer travels is similar, but less territorially polarised.

Regarding the accessibility, analysed at the regional level, wide zones appear of the poorly accessible internal peripheries, located most often within the borderlands of the particular provinces, or close to the national borders. The biggest areas of this type (visible first of all for the short travels) appear in:

- the belt surrounding Warsaw (all directions except for that towards Lodz);

- the middle Pomerania, in the borderland of the provinces of Western Pomerania, Pomerania, Cuiavia-Pomerania, and Wielkopolska;

- the north-eastern corner of the country (the borderland of Podlasie and Warmia-Masuria provinces);

- the Carpathian Mts., especially in Bieszczady Mts.

The improvement of the accessibility, both international and national (Fig. 3), due to the road projects, was not even in spatial terms. It was determined by the location of the routes constructed, and by the distribution of the demographic potential. The belt, featuring the highest advantages from these points of view, stretches from the German border, through central Poland to Warsaw, and then to Białystok, being related to the investment projects along the course of the A2 motorway and expressway S8. To the north of the A2 belt an improvement of accessibility appeared along the 
motorway A1 (up to the Tri-City), and, though to a much smaller extent, along the expressway S3 towards Szczecin. In southern Poland the role is particularly visible of the eastern segment of the motorway A4 (projects of the financial perspective of 2007-2013). Besides, one can perceive on the map the routes of S7 (between Warsaw and Cracow) and S8 (between Lodz and Wrocław). Their impact on the international accessibility demonstrates, inter alia, the changes in the setting of the shortest paths of travel along the road network towards the national boundaries. These shortest paths increasingly often are not identical with the shortest road lengths. Gravitation appears towards the motorways, as the routes featuring the highest travel velocities. Regarding short travels the so-called tunnel effect can be perceived between some of the motorway nodes. The spatial units, cut across by the new road developments, do not gain in terms of the changes in international accessibility to the extent expected owing to the disadvantageous location of the nodes. A decrease of accessibility over the segments between the nodes can be observed for the concessionary fragments of the motorways $\mathrm{A} 1$ and A2, and in the eastern part of the motorway A4. The effect is virtually imperceptible in the neighbourhood of the newly established expressways. This is a confirmation of the proposition that, generally, motorways may to a higher extent generate the tunnel effect (understood here as the limitation to the international contacts) than this is the case with the expressways (Komornicki et al. 2013).

With respect to the long travels, the belts of improvement of the international accessibility are distinctly broader. The advantages, which accrue with this regard to the broadly conceived Eastern Poland, become visible to a bigger extent. At the same time, there are places, where asymmetry of the belts of improved accessibility is observed. This is the case, in a particular manner, of the eastern segment of the A4 motorway, which exerts a far-reaching influence on the areas, neighbouring with it to the north (up to the province of Lublin), while influencing much weaker the geographically closer units within the Polish-Slovak borderland. This is the effect of the relief, but also, again, of the location of nodes.

Comparison was carried out, as well, in the setting of provinces (Table 3). Additionally, the values of the indicator were calculated without considering the own potential of the units. This made possible the assessment of the degree, to which the change in accessibility depends upon the location of the project with respect to large centres. The role of the own potential turned out to be significant only in a couple of cases (roads, leading towards the large masses). This became apparent in the province of Masovia (the motorway A2 and the road S8 to Warsaw), and in the provinces of Pomerania and Cuiavia-Pomerania (the motorway A1 to Gdańsk). The highest relative improvement of the international accessibility took place in the provinces of Wielkopolska, Lodz, Subcarpathia, Ciuavia-Pomerania, and Upper Silesia. In these terms the poorest effects of the road-related investments were observed in the provinces of Western Pomerania, Warmia-Masuria, Podlasie, and Lublin.

The study performed enabled, as well, the pinpointing of the areas, which, in the period following 2004, have not improved their position regarding the European-level road accessibility. Paradoxically, these are, in particular, the belts along the German and Czech borders. The geographical affinity of the network of German (and to a lesser extent also Czech) motorways caused that the international accessibility had been quite satisfactory on these areas already before the accession to the European Union. On the other hand, the areas affected by the values of the indicator, corresponding to the relatively peripherally located territories, were: middle Pomerania, and, to a somewhat lower degree, also the northern part of the province of Masovia, and the provinces of Masuria, Lublin, and Subcarpathia. In the latter of the territories mentioned this was especially noticeable in the shorter travels. At the same time, it should be remembered that the relatively high increases in the values 
of the international accessibility indicator within the broadly conceived eastern Poland were largely the effect of the low starting point.

Comparison of the changes in the international and national accessibility makes it possible to indicate the areas, in which the road-related investment projects served more the improvement of the international accessibility. These areas include eastern Poland (owing to the parallel A2 and A4 projects), and the peripheral areas of Wielkopolska. At the same time, the Polish-German borderland gained decidedly more in the national dimension. Generally, the change in the international accessibility in the years 2004-2013 amounted to approximately 22\% and was by close to 4 percentage points bigger than the change in the national accessibility (long travels, Table 3). Altogether, the international accessibility improved more in the east of Poland, the national accessibility - in the centre and in the west, while the regional accessibility - in the centre and in the south. The handicapped regions in each of these dimensions were middle Pomerania and north-western Masovia. The triple winners of the road projects turned out to be the area between Lodz and Warsaw, the southern part of Upper Silesia, and the town of Przemyśl.

Summing up, it should also be emphasised that in the periods of investment-based advance in transport (which was the case in Poland in the recent years) a differentiation takes place in the level of accessibility, perceived from the European, national, and regional perspectives. Some areas, which are relatively well accessible from the core of the European Union, remain peripheral on the national scale. The instance is provided by the regions of western Poland (especially the Lower Silesian province with its capital, Wrocław), which are increasingly well connected with the road network of Germany, while being transport-wise separated from the capital of Poland. Simultaneously, the situation is, additionally, internally differentiated in the region of Lower Silesia. Some of the local centres, situated in Sudety Mts. are very poorly accessible from Wrocław. A centre, which is well connected, transport-wise, at the national level, may turn out to be poorly accessible from its own hinterland, this having an influence on the magnitude of the labour market and the accessibility to social services. Such situations concern especially some metropolitan areas, struggling with permanent congestion. 

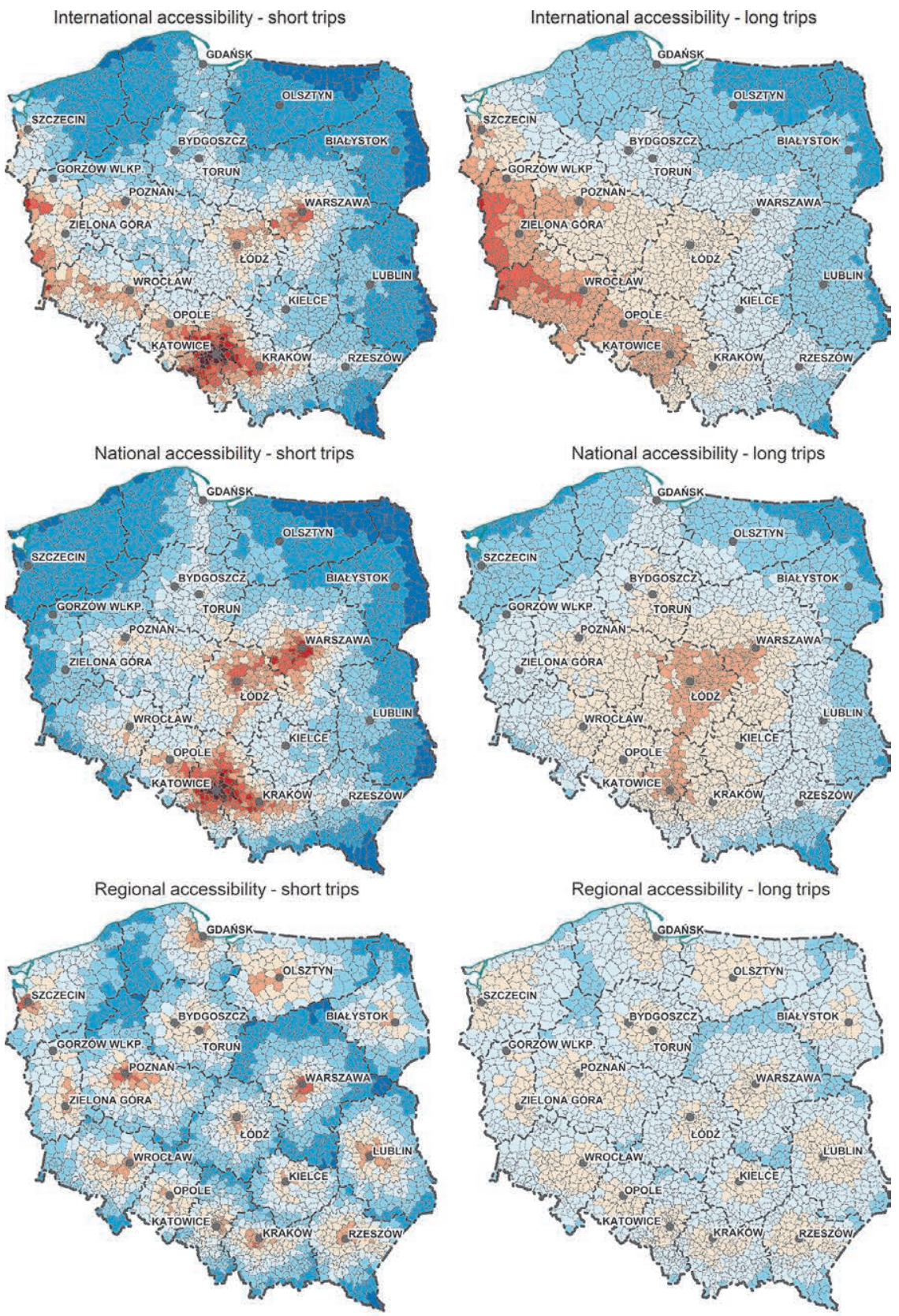

Potential accessibility
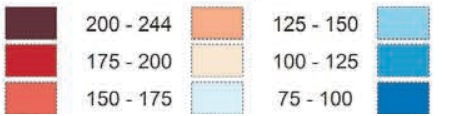

$50-75$

$25-50$

$150-175$

$75-100$

$10-25$

Figure 2. Potential accessibility of municipalities in Poland: the basic variant Source: own elaboration. 
Table 2. Differentiation of the level of potential spatial accessibility in the provinces with respect to the average (weighted by population) for entire Poland. The basic variant (2013)

\begin{tabular}{|c|c|c|c|c|c|c|c|c|c|c|c|c|}
\hline \multirow{3}{*}{ Province } & \multicolumn{6}{|c|}{ International accessibility } & \multicolumn{6}{|c|}{ National accessibility } \\
\hline & \multicolumn{3}{|c|}{ Short travels } & \multicolumn{3}{|c|}{ Long travels } & \multicolumn{3}{|c|}{ Short travels } & \multicolumn{3}{|c|}{ Long travels } \\
\hline & \begin{tabular}{|c|} 
Average \\
weighted by \\
population
\end{tabular} & \begin{tabular}{|l|} 
Municipal \\
minimum
\end{tabular} & $\begin{array}{l}\text { Municipal } \\
\text { maximum }\end{array}$ & $\begin{array}{c}\text { Average } \\
\text { weighted by } \\
\text { population }\end{array}$ & $\begin{array}{c}\text { Municipal } \\
\text { minimum }\end{array}$ & $\begin{array}{l}\text { Municipal } \\
\text { maximum }\end{array}$ & $\begin{array}{c}\text { Average } \\
\text { weighted by } \\
\text { population }\end{array}$ & $\begin{array}{l}\text { Municipal } \\
\text { minimum }\end{array}$ & $\begin{array}{l}\text { Municipal } \\
\text { maximum }\end{array}$ & $\begin{array}{c}\text { Average } \\
\text { weighted by } \\
\text { population }\end{array}$ & $\begin{array}{l}\text { Municipal } \\
\text { minimum }\end{array}$ & $\begin{array}{l}\text { Municipal } \\
\text { maximum }\end{array}$ \\
\hline Lower Silesia & 112.3 & 64.8 & 176.4 & 140 & 112.7 & 179.9 & 86.4 & 28.7 & 125.5 & 98.7 & 66 & 117.5 \\
\hline Cuiavia-Pomerania & 75.2 & 44.4 & 102.9 & 86.1 & 64.9 & 104 & 86.3 & 51.5 & 119.2 & 101.4 & 77.9 & 124.4 \\
\hline Lublin & 48.4 & 16.4 & 70 & 63 & 45.5 & 76.3 & 54.6 & 15.5 & 81.6 & 76.9 & 46.9 & 99.6 \\
\hline Lubusza & 108.3 & 51.4 & 199.4 & 141 & 100.1 & 175.5 & 57.5 & 32.6 & 80 & 84.5 & 70.8 & 97 \\
\hline Lodz & 114.7 & 60.6 & 147.8 & 111.6 & 90.6 & 124.9 & 130.8 & 67.4 & 169.9 & 131.6 & 107.2 & 143.6 \\
\hline Małopolska & 122.6 & 42.5 & 208.9 & 106.1 & 72.5 & 134.9 & 125.9 & 30.3 & 213.5 & 105.5 & 59.9 & 132.9 \\
\hline Masovia & 113.4 & 32.6 & 170.3 & 89.7 & 53.1 & 112.4 & 132.7 & 35.7 & 199.5 & 116.5 & 68.2 & 141.8 \\
\hline Opole & 117.9 & 73.1 & 183.9 & 129.6 & 106 & 143 & 109.3 & 54.8 & 172.9 & 110.8 & 83.4 & 125.4 \\
\hline Subcarpathia & 63.4 & 12.8 & 95.3 & 78.1 & 43.7 & 94.2 & 67.3 & 10.6 & 104.3 & 81.3 & 37.6 & 100 \\
\hline Podlasie & 38.9 & 14.4 & 60.5 & 54.6 & 38.3 & 71.5 & 39.1 & 12 & 69.3 & 62.3 & 34.9 & 89.5 \\
\hline Pomerania & 57.8 & 17.9 & 80.4 & 60.9 & 40.1 & 76.5 & 67 & 20.3 & 93.6 & 75.1 & 45.4 & 97.6 \\
\hline Silesia & 180.8 & 80.7 & 242.9 & 131.6 & 100.2 & 147.3 & 170.2 & 56.3 & 243.3 & 123 & 79.8 & 138.6 \\
\hline Świętokrzyskie & 73 & 52.3 & 93 & 85.6 & 70.7 & 102.9 & 83.4 & 61 & 100.5 & 106 & 91.1 & 117.7 \\
\hline Warmia-Masuria & 37.6 & 18.4 & 52.9 & 52.3 & 37.4 & 68.5 & 41.3 & 12.1 & 59.5 & 66.5 & 35.1 & 88.4 \\
\hline Wielkopolskie & 90.8 & 38.5 & 136.5 & 115.5 & 70 & 142.8 & 89.7 & 41.3 & 130.7 & 104.9 & 69.1 & 131.6 \\
\hline Western Pomerania & 66.8 & 22.8 & 135.7 & 101.1 & 54.2 & 139.8 & 37.1 & 13.3 & 51.7 & 57.1 & 38 & 72.9 \\
\hline Poland & - & 12.8 & 242.9 & - & 37.4 & 179.9 & - & 10.6 & 243.3 & - & 34.9 & 143.6 \\
\hline
\end{tabular}

Source: own elaboration. 

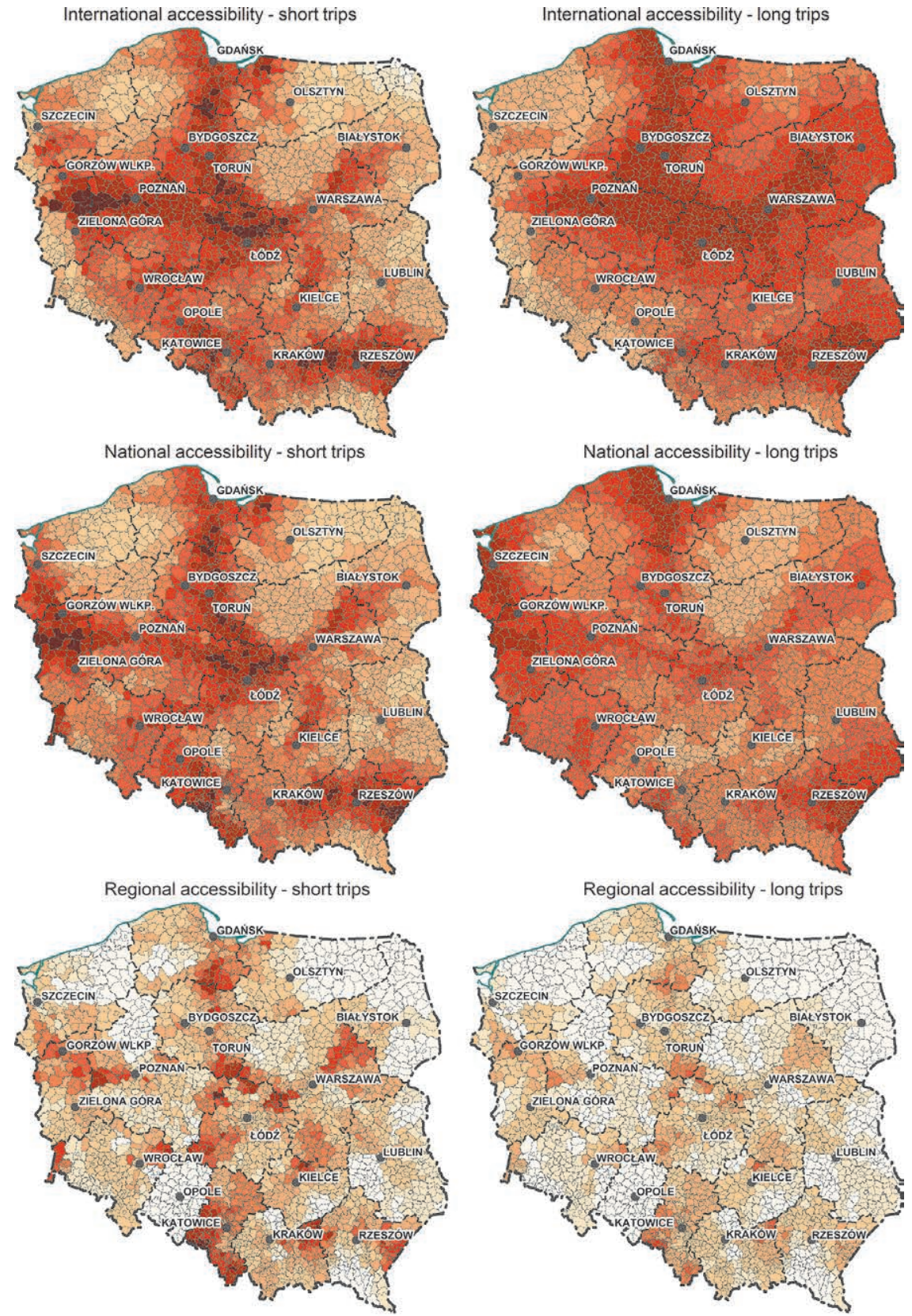

Relative change of potential accessibility $(100 \%=2004$ year $)$
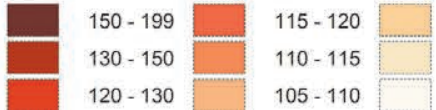

$$
\begin{aligned}
& 102-105 \\
& 101-102 \\
& 100-101
\end{aligned}
$$

Figure 3. Changes in the levels of the potential accessibility in the years 2004-2013 Source: own elaboration. 
Table 3. Change in the potential spatial accessibility in the provinces in the years $2004-2013(2004=100 \%)$

\begin{tabular}{|c|c|c|c|c|c|c|c|c|}
\hline \multirow{3}{*}{ Provinces } & \multicolumn{4}{|c|}{ International accessibility } & \multicolumn{4}{|c|}{ National accessibility } \\
\hline & \multicolumn{2}{|c|}{ Short travels } & \multicolumn{2}{|c|}{ Long travels } & \multicolumn{2}{|c|}{ Short travels } & \multicolumn{2}{|c|}{ Long travels } \\
\hline & $\begin{array}{c}\text { Total } \\
\text { change }\end{array}$ & $\begin{array}{c}\text { Change in external } \\
\text { accessibility }^{*}\end{array}$ & $\begin{array}{l}\text { Total } \\
\text { change }\end{array}$ & $\begin{array}{c}\text { Change in external } \\
\text { accessibility }^{*}\end{array}$ & $\begin{array}{l}\text { Total } \\
\text { change }\end{array}$ & $\begin{array}{l}\text { Change in external } \\
\text { accessibility }^{*}\end{array}$ & $\begin{array}{l}\text { Total } \\
\text { change }\end{array}$ & $\begin{array}{l}\text { Change in external } \\
\text { accessibility }^{*}\end{array}$ \\
\hline Lower Silesia & 114.3 & 115.6 & 110.2 & 110.3 & 116.3 & 118.6 & 119.1 & 119.6 \\
\hline Cuiavia-Pomerania & 129.2 & 132.1 & 133.3 & 133.6 & 126.4 & 129.1 & 118.3 & 118.6 \\
\hline Lublin & 108.1 & 108.9 & 122 & 122.2 & 108 & 108.8 & 114.6 & 114.8 \\
\hline Lubusza & 119.4 & 119.9 & 111 & 111 & 127.8 & 129.6 & 125.6 & 125.8 \\
\hline Lodz & 132.3 & 136.8 & 133.7 & 134.2 & 129.2 & 133.4 & 118.1 & 118.5 \\
\hline Małopolska & 120.3 & 122.2 & 119.3 & 119.5 & 117.3 & 119.3 & 114.6 & 114.9 \\
\hline Masovia & 116.1 & 121.6 & 132.5 & 134 & 115.3 & 120.5 & 116 & 117.1 \\
\hline Opole & 121.7 & 122.1 & 110.2 & 110.3 & 123.1 & 123.6 & 114.1 & 114.2 \\
\hline Subcarpathia & 128.6 & 129.9 & 128.8 & 128.9 & 128.3 & 129.7 & 122.9 & 123.1 \\
\hline Podlasie & 109.1 & 110.5 & 125.3 & 125.6 & 110.6 & 112.6 & 117.1 & 117.4 \\
\hline Pomerania & 123.5 & 127.5 & 130.2 & 130.7 & 122.7 & 126.6 & 132.9 & 133.9 \\
\hline Silesia & 128.8 & 130 & 118.5 & 118.6 & 122.7 & 123.9 & 115 & 115.2 \\
\hline Świętokrzyskie & 116.2 & 116.9 & 118.4 & 118.4 & 114.5 & 115.2 & 111.5 & 111.5 \\
\hline Warmia-Masuria & 110.5 & 111.4 & 118.9 & 119 & 110.5 & 111.4 & 110.7 & 110.8 \\
\hline Wielkopolskie & 132.9 & 135.7 & 130.3 & 130.5 & 120.3 & 122.1 & 118.2 & 118.5 \\
\hline Western Pomerania & 107.8 & 108.5 & 107.3 & 107.4 & 111.8 & 114.8 & 123.3 & 123.9 \\
\hline Poland & 122,1 & 124.7 & 121.9 & 122.1 & 119.8 & 122.4 & 117.4 & 117.8 \\
\hline
\end{tabular}

* not considering the (unchanged) own potential

Source: own elaboration. 


\section{Ex-post evaluation of the changes in spatial accessibility: the case studies}

The analysis of changes in accessibility was carried out, additionally, for each of the new road projects, which were subject to inquiry in the framework of the case studies. The results of these analyses are presented in the cartographic form (Figs. 4, 5 and 6). In the case of the investigated segment of A1 motorway the areas of improvement in international and national accessibility are almost identical (Fig. 4). This means that the project realised provides the main route, leading traffic out of the Tri-City both in the direction of all the important national centres, and towards the essential foreign destinations (i.e. towards the German and Czech borders). Advantages from this project are gained by almost entire province of Pomerania (except for its south-western fringe), the entire province of Cuiavia-Pomerania, and the northern part of the Warmian-Masurian province. The positive impact is also visible farther south in central Poland and within the eastern peripheries of the Western Pomeranian province. The spatial setting observed is, however, different in the case of results, assessed at the regional level. The belt of advantages has a parallel course and encompasses, first of all, the southern edge of the Pomeranian province. It is characteristic that in this perspective the construction of A1 motorway brings benefits also to the municipalities, located within the south-western fringes of the province, these municipalities forming the sole area that did not benefit from this project in the international and national perspectives. This situation is the consequence of the low quality (throughput capacity) of the alternative road routes, linking these areas with the Tri-City. In such conditions the fastest road routes are longer in geographical terms, but including the motorway A1 over definite segments. On the other hand, the influence of this project on the regional accessibility is much lower in the northern part of the province.

In the case of the analysed segment of the A4 motorway (Fig. 5) the differences between the spatial distributions of improvement in the international and national accessibility are more significant. The internal advantages encompass the entire province of Lower Silesia and Opole (except for the northern municipalities of the letter), and partly also the provinces of Lubusza, Upper Silesia, and Małopolska. The international accessibility improved, as well, in the regions mentioned, but, as a rule, over smaller areas. This applies also to the Lower Silesian province, whose border areas (both along the border with Germany, and with Czechia) benefit from the project in question, in the international perspective, to a much smaller degree. The reach of influence is significantly bigger for the long travels (such a difference with this respect was not observed for the case of A1). In the international dimension this reach extends, first of all, to the east (along the sequence of segments of A4), and in the national dimension - towards the north, in connection with the expressway S3. These differences show the role, played by the A4 motorway (over the segment here analysed) for the various regions of the country. For such provinces as Upper Silesia, Małopolska, and Subcarpathia, the project considered contributed primarily to a better connection with the destinations in Western Europe. For the provinces of western Poland it shortened the travel time to the Upper Silesian economic pole. The existence of bigger differentiation of results than in the case of A1 is also to some extent due to the network effect (A4 motorway is ready over the major part of its length, while A1 still has significant gaps in its central segment). The reach of effects on the regional scale is spatially smaller than that observed in the case of A1. It is limited almost exclusively to the province of Opole and the western fringe of Lower Silesia. 


\section{A1 Pruszcz Gdański-Grudziądz}
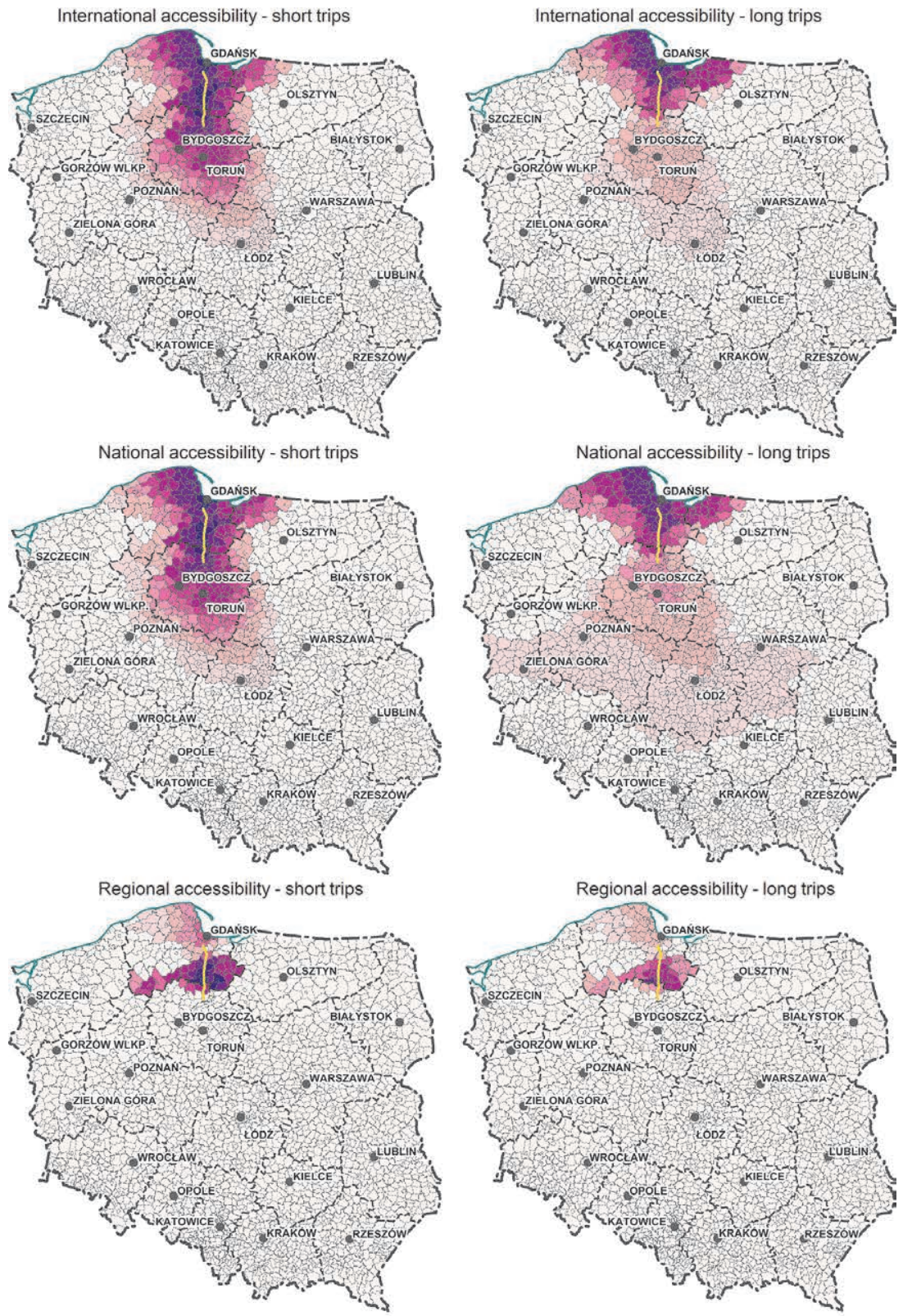

Relative change of potential accessibility (\%)

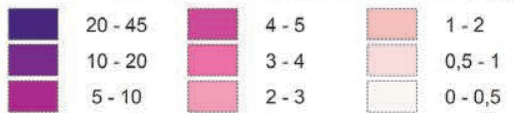

Figure 4. Changes in spatial accessibility in the effect of realisation of the A1 motorway project between

Pruszcz Gdański and Grudziądz

Source: own elaboration. 


\section{A4 Wroctaw-Opole}
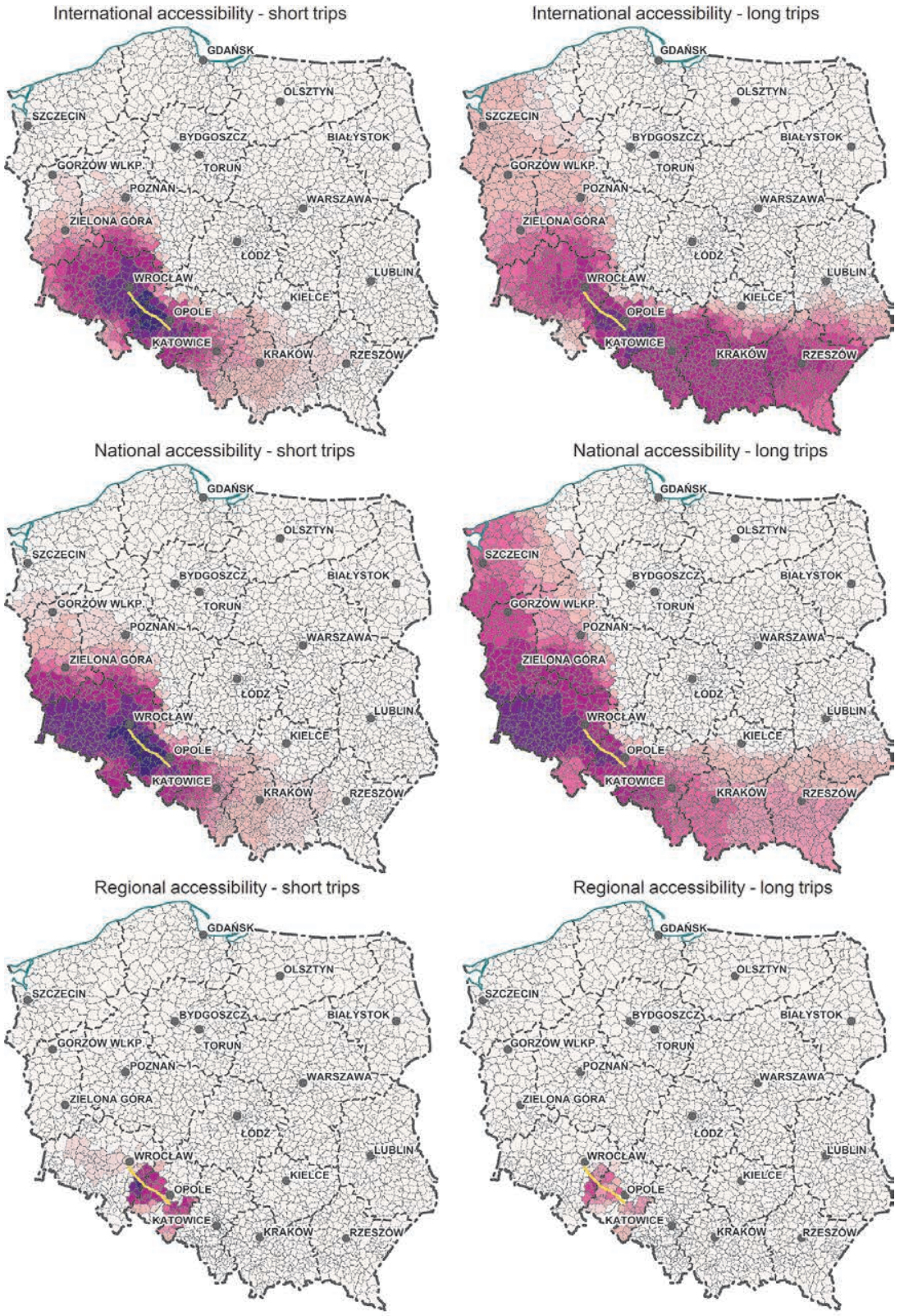

Relative change of potential accessibility (\%)
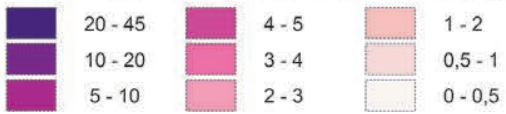

Figure 5. Changes in spatial accessibility in the effect of realisation of the A4 motorway project between Wrocław and Opole

Source: own elaboration. 
S8 Radzymin-Wyszków
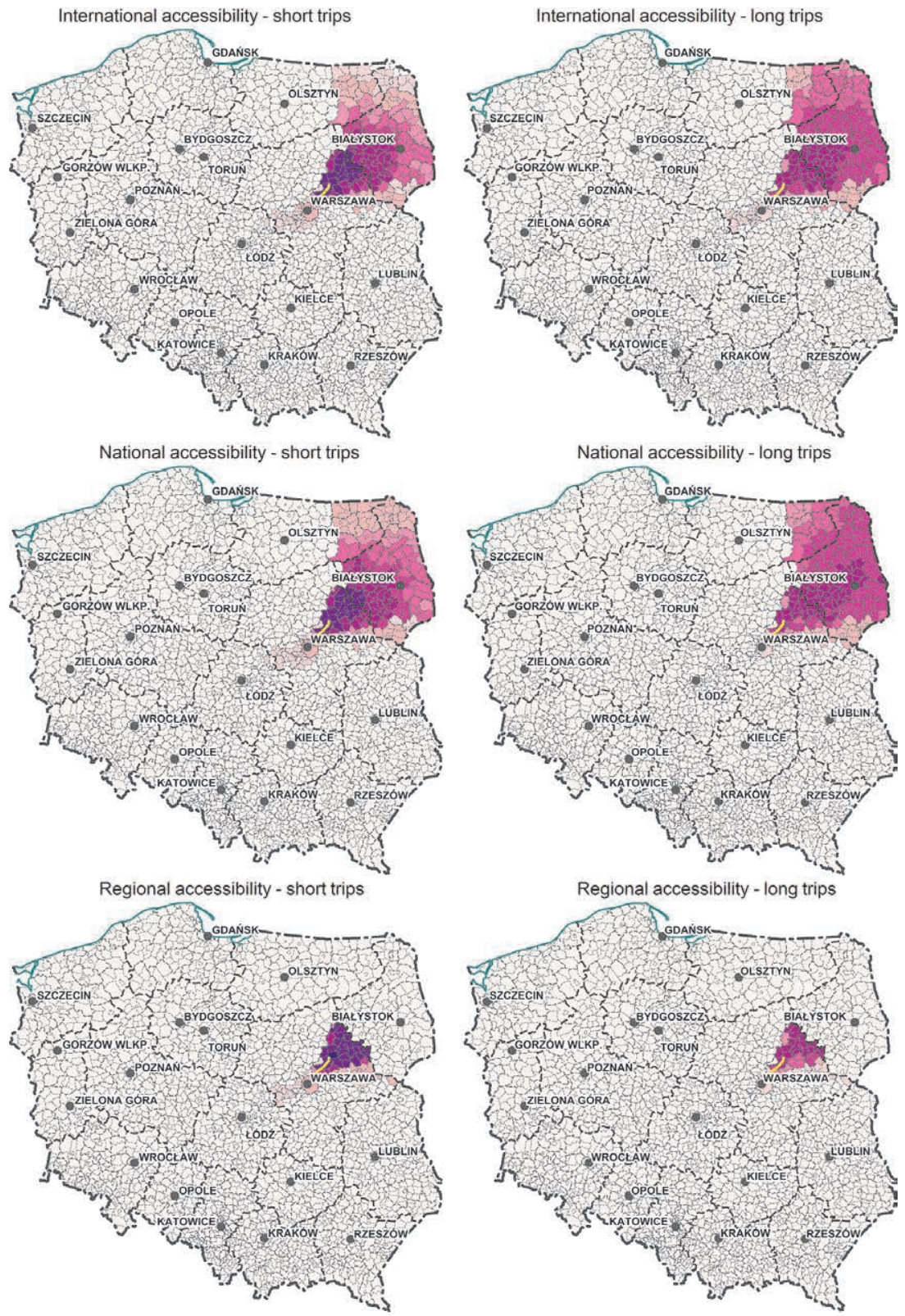

Relative change of potential accessibility (\%)
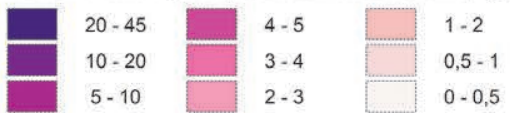

Figure 6. Changes in spatial accessibility in the effect of realisation of the S8 road project between Radzymin and Wyszków Source: own elaboration. 
The distributions of accessibility-related effects of the project linked with the segment of the S8 expressway in the vicinity of Warsaw (Fig. 6) display quite specific features. Location of this segment to the east of Warsaw determines the spatial configuration of the advantages. These effects are, in fact, territorially identical for the national and international perspectives, as well as for the short and long travels. The respective area has the fan-like shape, encompassing the entire province of Podlasie, the north-eastern part of Masovia, and the eastern part of Warmia-Masuria. In the setting of provinces the decidedly biggest winner is the province of Podlasie, despite the fact that the road segment in question is entirel contained in the province of Masovia. This is a confirmation of the proposition that the improvement in accessibility may take place in effect of the projects situated relatively far from the area considered. Regarding the regional accessibility the spatial reach of the advantages, resulting from construction of this segment of S8 road is the smallest among those analysed here. It is limited to the municipalities, neighbouring upon the road itself, and its extension towards Białystok. At the same time, the percentage scale of the improvement in accessibility is very high. In this context, the significance of this road segment for job commuting towards Warsaw can hardly be overestimated.

\section{Conclusions}

Improvement in the international and national accessibility, which took place in Poland in the effect of realisation of road projects, was highly uneven in spatial terms. This was determined by the locations of the routes constructed, and by the distribution of the demographic potential. The spatial distribution of accessibility became more polarised, this being unavoidable in the case of undertaking numerous projects over a short time span.

The belt, characterised by the highest benefits in the sense here considered, stretched from the German border through central Poland and farther towards Białystok, being related to the course of A2 motorway and the expressway S8. To the north of the A2 belt the improvement of accessibility appeared along the A1 motorway (up to the Tri-City at the coast), and, though to a much lower degree, along the expressway S3 in the direction of Szczecin. In southern Poland, an important role was played by the eastern part of the A4 motorway (investment project of the financial perspective of 2007-2013), while the role of its western segment, between Bolesławiec and Zgorzelec, was distinctly lower. Besides, he maps of changes in accessibility make apparent the effect of the projects, carried out along the routes of S7 (between Warsaw and Cracow) and S8 (between Lodz and Wrocław). Altogether, the values of the indicator in the national perspective improved more distinctly in central Poland, while in the international perspective - mainly in eastern Poland. Improvement at the regional level has an insular character, appearing primarily within the borderlands of the province, through which a given road project passed.

This allows for a careful statement that the road investments realised served to a higher extent the international and inter-metropolitan connections, their contribution to the improvement of the situation in the provinces being smaller. One of the reasons was lack of some road investments in the vicinity of large metropolises, which limited the potential benefits (loss of time at the city entry points).

Some areas, through which new projects passed, did not improve their national and international accessibility to the extent possible in view of the erroneous (too sparse) location of nodes. The study confirmed the earlier apprehensions that the motorways might produce the tunnel effect (understood as the limitations regarding the longer-distance connections). This kind of threat is distinctly smaller 
for the expressways. It was also demonstrated that the correct location of nodes may have a perceptible influence on the spatial reach of the positive effect from the projects realised. Likewise, it was confirmed that investment projects, undertaken in some regions, may significantly improve accessibility of the areas located relatively farm from them - including the peripheral areas, as well. The latter concerns, in a particular manner, the examples of areas from eastern Poland, where accessibility has importantly improved (first of all in the international perspective), due to the construction of motorways and expressways in central, and even in western Poland.

\section{References}

ESPON 1.1.3. Final Report, 2006, www.espon.eu

ESPON 1.2.1. Final Report, 2004, www.espon.eu

ESPON FOCI Final Report, 2010, www.espon.eu

ESPON SeGI Interim Report, 2012, www.espon.eu

ESPON TRACC Interim Report, 2012, www.espon.eu

Fotheringham A.S., O’Kelly M.E., 1989. Spatial Interaction Models. Dordrecht: Kluwer.

Geurs K.T., Eck R. van, 2001. Accessibility Measures: Review and Applications. RIVM report 408505 006. National Institute of Public Health and the Environment, Bilthoven.

Geurs K.T., Ritsema van Eck J.R., 2001. Accessibility Measures: Review and Applications. RIVM report 408505 006. National Institute of Public Health and the Environment, Bilthoven.

Geurs K.T., van Wee B., 2004. Accessibility evaluation of land-use and transport strategies: review and research directions. Journal of Transport Geography, 12(2), pp. 127-140.

Gutiérrez J., 2001. Location, economic potential and daily accessibility: an analysis of the accessibility impact of the high-speed line Madrid-Barcelona-French border. Journal of Transport Geography, 9, pp. 229-242.

Gutiérrez J., Condeço-Melhorado A., López E., Monzón A., 2011. Evaluating the European added value of TEN-T projects: a methodological proposal based on spatial spillovers, accessibility and GIS. J. Transp. Geogr., 19(4), pp. 840-850.

Hansen W.G., 1959. How Accessibility Shapes Land-use. J. Am. Inst. Plannners, 25, pp. $73-76$.

Hansen W.G., 1959. How Accessibility Shapes Land-use. Journal of the American Institute of Planners, 25 , pp. 73-76.

Harris C.D., 1954. The market as a Factor in the Localization of Industry in the United States. Ann. Assoc. Am. Geogr., 44, pp. 315-348.

Holl A., 2007. Twenty years of accessibility improvements. The case of the Spanish motorway building programme. J. Transp. Geogr., 15(4), pp. 286-297.

KMR, 2008. Krajowy Model Ruchu. Studium układu dróg szybkiego ruchu w Polsce. Warszawa: GDDKiA.

Komornicki T., 2013. Infrastruktura Transportowa. [in:] A. Olechnicka, K. Wojnar (eds.). Terytorialny wymiar rozwoju. Polska z perspektywy badań ESPON. Warszawa: ESPON, pp. 104-117.

Komornicki T., Bański J., Śleszyński P., Rosik P., Świątek D., Czapiewski K., Bednarek-Szczepańska M., Stępniak M., Mazur M., Wiśniewski R., Solon B., 2011. Ocena wptywu inwestycji infrastruktury transportowej realizowanych $w$ ramach polityki spójności na wzrost konkurencyjności regionów (w ramach ewaluacji ex post NPR 2004-2006). Narodowa Strategia Spójności. Warszawa: Ministerstwo Rozwoju Regionalnego, 131 pp. 
Komornicki T., Rosik P., Śleszyński P., Solon J., Wiśniewski R., Stępniak M., Czapiewski K., Goliszek S., 2013. Wpływ budowy autostrad i dróg ekspresowych na rozwój społeczno-gospodarczy i terytorialny Polski. Warszawa: Ministerstwo Rozwoju Regionalnego, 215 p.

Komornicki T., Śleszyński P., Rosik P., Pomianowski W., 2010. Dostęność przestrzenna jako przesłanka kształtowania polskiej polityki transportowej. Biuletyn KPZK 241, Warszawa: Komitet Przestrzennego Zagospodarowania Kraju PAN, 167 pp.

Korcelli P., Degórski M., Drzazga D., Komornicki T., Markowski T., Szlachta J., Węcławowicz G., Zaleski J., Zaucha J., 2010. Ekspercki projekt koncepcji przestrzennego zagospodarowania kraju do roku 2033. Studia KPZK, volume CXXVIII, Warszawa: KPZK PAN, 170 pp.

Kotavaara O., Antikainen H., Rusanen J., 2011. Population change and accessibility by road and rail networks: GIS and statistical approach to Finland 1970-2007. J. Transp. Geogr., 19(4), pp. 926-935.

Rich D.C., 1978. Population potential, potential transportation cost and industrial location. Area, 10, pp. 222-226.

Rosik P., 2012. Dostępność lądowa przestrzeni Polski w wymiarze europejskim. Warszawa: IGiPZ PAN.

Rosik P., Pomianowski W., Stępniak M., Komornicki T., Śleszyński P., 2011. Narzędzie ewaluacyjno-badawcze dostęności transportowej gmin w podukładach wojewódzkich. Final report. Unpublished material elaborated in the farmework of the IVth competition for subsidies of the Ministry of Regional Development, Warszawa.

Spiekermann K., Schürmann C., 2007. Update of selected potential accessibility indicators. Final report. Spiekermann \& Wegener, Urban and Regional Research (S\&W), RRG Spatial Planning and Geoinformation.

Spiekermann K., Wegener M., Květoň V., Marada M., Schürmann C., Biosca O., Ulied Segui A., Antikainen H., Kotavaara O., Rusanen J., Bielańska D., Fiorello D., Komornicki T., Rosik P., Stepniak M., 2013. TRACC Transport Accessibility at Regional/Local Scale and Patterns in Europe. Draft Final Report. ESPON Applied Research.

Stępniak M., Rosik P., 2013. Accessibility improvement, territorial cohesion and spillovers: a multidimensional evaluation of two motorway sections in Poland. Journal of Transport Geography, vol. 31, pp. 154-163.

Warsaw Traffic Survey, 2005. BPRW S.A., Warszawa.

Więckowski M., Michniak D., Bednarek-Szczepańska M., Chrenka B., Ira V., Komornicki T., Rosik P., Stępniak M., Szekely V., Śleszyński P., Świątek D., Wiśniewski R., 2014. Road accessibility to tourist destinations of the Polish-Slovak borderland: 2010-2030 prediction and planning. Geographia Polonica, 87, 1, pp. 5-26. 